Pacific Northwest

National Laboratory

Operated by Battelle for the

U.S. Department of Energy

\section{Assessment of Impacts from Updating Iowa's Residential Energy Code to Comply with the 2003 International Energy Conservation Code}

R. G. Lucas

October 2003

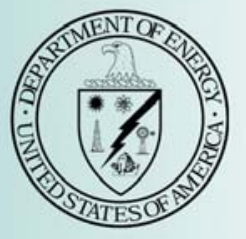

Prepared for the U.S. Department of Energy under Contract DE-AC06-76RL01830 


\title{
DISCLAIMER
}

This report was prepared as an account of work sponsored by an agency of the United States Government. Neither the United States Government nor any agency thereof, nor Battelle Memorial Institute, nor any of their employees, makes any warranty, express or implied, or assumes any legal liability or responsibility for the accuracy, completeness, or usefulness of any information, apparatus, product, or process disclosed, or represents that its use would not infringe privately owned rights. Reference herein to any specific commercial product, process, or service by trade name, trademark, manufacturer, or otherwise does not necessarily constitute or imply its endorsement, recommendation, or favoring by the United States Government or any agency thereof, or Battelle Memorial Institute. The views and opinions of authors expressed herein do not necessarily state or reflect those of the United States Government or any agency thereof.

\author{
PACIFIC NORTHWEST NATIONAL LABORATORY \\ operated by \\ BATTELLE \\ for the \\ UNITED STATES DEPARTMENT OF ENERGY \\ under Contract DE-ACO6-76RL0183O
}

Printed in the United States of America

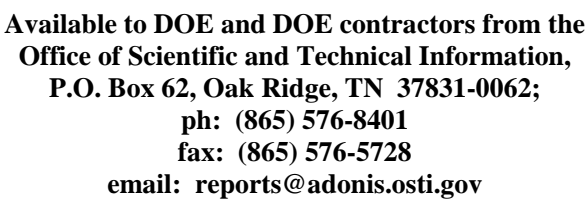

Available to the public from the National Technical Information Service, U.S. Department of Commerce, 5285 Port Royal Rd., Springfield, VA 22161 ph: (800) 553-6847 fax: (703) 605-6900

email: orders@ntis.fedworld.gov

online ordering: http://www.ntis.gov/ordering.htm 


\title{
Assessment of Impacts from Updating Iowa's Residential Energy Code to Comply with the 2003 International Energy Conservation Code
}

\author{
R.G. Lucas
}

October 2003

Prepared for

the U.S. Department of Energy

under Contract DE-AC06-76RLO 1830

Pacific Northwest National Laboratory

Richland, Washington 99352 


\section{Summary}

The state of Iowa currently requires that new buildings comply with the Council of American Building Officials' (CABO) 1992 Model Energy Code (MEC) (CABO 1992). CABO has been transformed into the International Code Council (ICC) and the MEC has been renamed the International Energy Conservation Code (IECC). The most recent edition of the code is the 2003 IECC (ICC 2003). Iowa's Department of Natural Resources requested that the U.S. Department of Energy (DOE) compare the 1992 MEC with the 2003 IECC to estimate impacts from updating Iowa's residential energy code to comply with the new code. Under DOE's direction, Pacific Northwest National Laboratory (PNNL) completed an assessment of the impacts from this potential code upgrade, including impacts on construction and energy consumption costs. This report is an update to a similar report completed by PNNL in 2002 (Lucas 2002) that compared the 1992 MEC to the 2000 IECC.

Despite the change in the code's appearance, most of the requirements for residential buildings in the 1992 MEC and 2003 IECC have similar energy efficiency requirements. Some specific requirements in the 2003 IECC are more stringent than those in the 1992 MEC. The most significant differences between the 1992 MEC and the 2003 IECC for residential buildings in Iowa are as follows:

- The thermal wall requirements for multifamily buildings have become substantially more stringent in the 2003 IECC-the allowed heat loss rates are about one-third lower than those allowed in the 1992 MEC. Despite this improvement, the requirements in the IECC for many multifamily buildings will be less-stringent than those for the typical single-family house.

- Specific provisions have been added to the 2003 IECC for recessed lighting fixtures to limit heat loss/gain by air infiltration.

The 1992 MEC and 2003 IECC have numerous other differences, but most of these differences are minor and will likely have little or no impact on energy efficiency or construction costs for most residential buildings. The 2003 IECC is much larger than 1992 MEC and has been restructured considerably from the MEC. Some changes affect only certain regions of the United States that do not include Iowa. Notable other code differences affecting Iowa include the following:

- Windows now have to be rated by the National Fenestration Ratings Council or be assigned an unfavorable $\mathrm{U}$-factor, which establishes credible ratings for window performance.

- Foam insulation on the exterior of foundation walls must have a protective covering when above grade.

The impacts on construction costs and energy savings from updated residential energy efficiency standards vary depending on several factors, including the type of dwelling and specific design elements. Some residential buildings would need several improvements to comply with an upgraded energy code; others may comply unchanged. For example, the thermal envelope requirements for multifamily buildings have become considerably more stringent, but the requirements for single-family houses are unchanged. Construction cost increases from 
adopting the 2003 IECC are expected to vary from zero to about $\$ 500$ for most houses or multifamily dwelling units. Many buildings should have no construction cost increases. The main cost impacts are expected to be from:

- envelope improvements to multifamily buildings (up to about $\$ 500$ per unit)

- a protective covering for exposed exterior foundation insulation (up to about $\$ 200$ if applicable)

- improved sealing for recessed light fixtures (up to \$50 or more, depending on the number of fixtures)

- $\quad$ improved duct sealing, about $\$ 200$.

All of the changes to the 2003 IECC are clearly cost-effective with a simple payback of about 7 years or less, except the requirement for a protective covering for exposed exterior foundation insulation. This requirement was not cost-effective from an energy efficiency standpoint, but is valuable for improving long-term durability. 


\section{Contents}

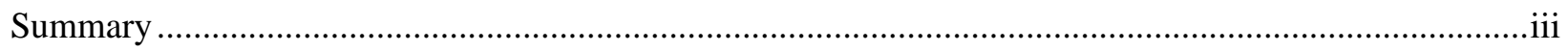

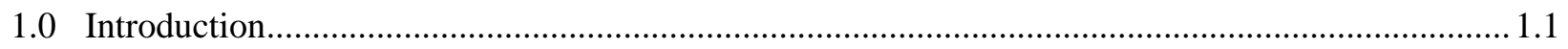

2.0 Impacts from Major Differences in 1992 MEC and 2003 IECC .................................................. 2.1

2.1 Thermal Wall Requirements for Multifamily Buildings ................................................... 2.1

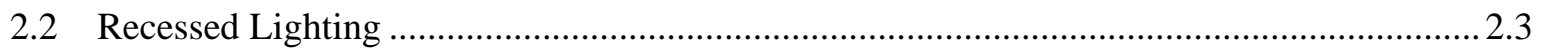

3.0 Impacts from Minor Differences 1992 MEC and 2003 IECC ....................................................... 3.1

3.1 Assumptions for Determining Wall $\mathrm{U}_{\mathrm{o}}$-Values for Wood-Frame Walls .............................. 3.1

3.2 Protective Covering for Exposed Foundation Insulation ............................................... 3.1

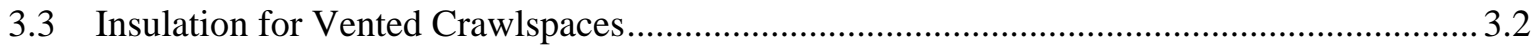

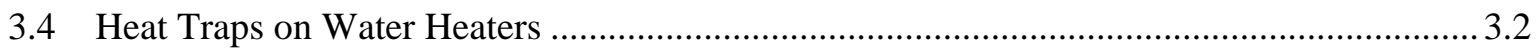

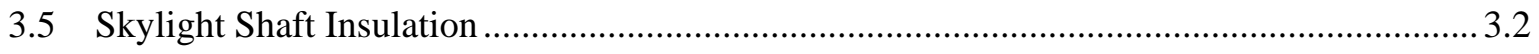

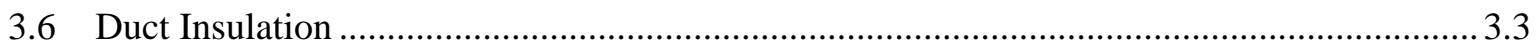

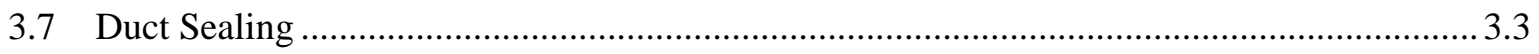

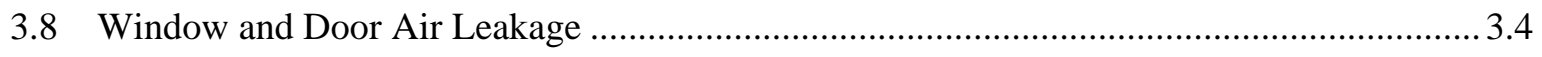

3.9 National Fenestration Rating Council Ratings ................................................................ 3.4

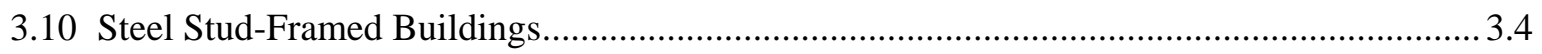

3.11 Prescriptive Path for Additions and Window/Skylight Replacement................................... 3.4

3.12 Optional Prescriptive Compliance Approaches - Section 502.2.4 and Chapter 6 ................. 3.5

3.13 Expanded Set of Rules for System Analysis Approach - Chapter 4.................................... 3.5

3.14 Solar Heat Gain Coefficient Requirement of 0.4 in Warm Climates ................................... 3.6

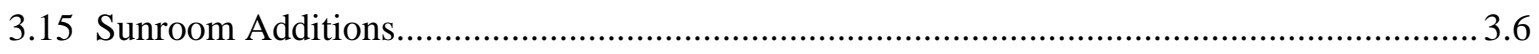

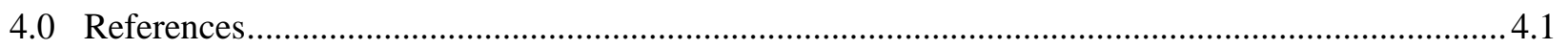

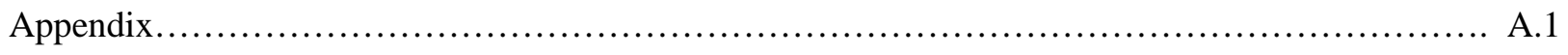




\subsection{Introduction}

The state of Iowa currently requires that new buildings comply with the Council of American Building Officials' (CABO) 1992 Model Energy Code (MEC) (CABO 1992). CABO has been transformed into the International Code Council (ICC) and the MEC has been renamed the International Energy Conservation Code (IECC). The most recent edition of the code is the 2003 IECC (ICC 2003). Iowa's Department of Natural Resources requested that the U.S. Department of Energy (DOE) compare the 1992 MEC with the 2003 IECC to estimate impacts from updating Iowa's residential energy code to comply with the new code. Under DOE's direction, Pacific Northwest National Laboratory (PNNL) completed an assessment of the impacts from this potential code upgrade, including impacts on construction and energy consumption costs. This report is an update to a similar report completed by PNNL in 2002 (Lucas 2002) that compared the 1992 MEC to the 2000 IECC.

This report contains the findings of this assessment. Section 2.0 discusses the impacts from major differences in the 1992 MEC and 2003 IECC and Section 3.0 discusses impacts from minor differences, including impacts on construction and energy costs. Section 4.0 contains a list of publications cited in this report. The Appendix provides an overview of the changes to the IECC from 2000 to 2003. Readers familiar with the 2002 report comparing the 2000 IECC to the 1992 MEC for Iowa (Lucas 2002) can find what has changed in the IECC since 2000 in this appendix. 


\subsection{Impacts from Major Differences in 1992 MEC and 2003 IECC}

This section discusses the most significant differences between the 1992 MEC and the 2003 IECC for residential buildings in Iowa: 1) the thermal wall requirements for multifamily buildings, and 2) provisions for recessed lighting fixtures to limit heat loss/gain by air infiltration. The IECC defines multifamily buildings as three stories or less above grade that contain three or more dwelling units (usually apartments or condominiums) as residential buildings and high-rise multifamily buildings as commercial buildings.

\subsection{Thermal Wall Requirements for Multifamily Buildings}

The component heat loss and heat gain $\left(\mathrm{U}_{\mathrm{o}}\right)$ requirements for multifamily residences changed dramatically between 1992 and 2003 (specifically in 1993).

The 2003 IECC has considerably more-stringent requirements for exterior walls (including windows and doors) in multifamily buildings than the 1992 MEC. These requirements are shown in Figure 1 (page 66) of the 1992 MEC and Figure 502.2(1) (page 19) of the 2003 IECC (which has the same requirements as the 2000 IECC). These requirements are reproduced in Figure 2.1 for the range of heating degree-days that encompass Iowa climates.

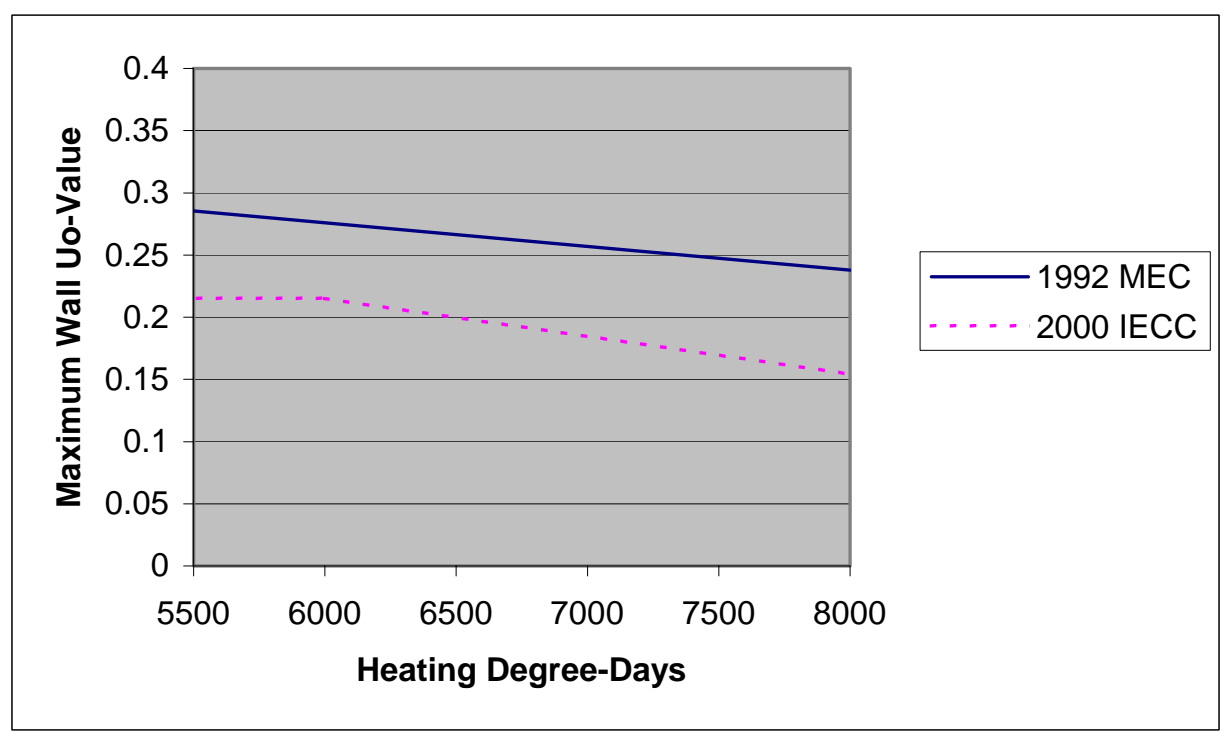

Figure 2.1. Thermal Wall Requirements for Multifamily Residences in Iowa

The REScheck ${ }^{\mathrm{TM}}$ software illustrates examples of the differences in window U-factor and wall insulation requirements between the 1992 MEC and 2003 IECC for multifamily buildings (see Table 2.1). The packages in this table are for a building with a window-to-wall area percentage of $20 \%$. The MEC and IECC establish requirements for exterior walls (including windows and doors) that vary as a function of the window area as a percentage of the gross wall area. Window U-factor and wall insulation requirements become more stringent as the window area percentage increases and less stringent as the window area percentage decreases. We assumed the building was two stories with six, $1100-\mathrm{ft}^{2} \mathrm{dwelling}$ 
units. The building was 27.5 - $\mathrm{ft}$ wide and 120 -ft long, with a total wall area of $4720 \mathrm{ft}^{2}$ and a window area of $944 \mathrm{ft}^{2}$ for the whole building, or $157 \mathrm{ft}^{2}$ per dwelling unit.

The requirements for multifamily residences in the 1992 MEC are lenient and would probably not result in any more energy efficiency than would occur in a free market in Iowa with no energy code. The 1992 MEC includes packages that allow multifamily residences with no basement or slab insulation to comply. Alternately, if the basement or slab is insulated, very lenient energy efficiency measures can be used elsewhere in the building, such as R-19 ceiling insulation and double-pane aluminum windows (perhaps even single-pane). The envelope requirements for multifamily buildings in the 2003 IECC are more in line with the IECC's requirements for single-family buildings, although multifamily buildings will often still have less-stringent requirements than are required for houses. About $30 \%$ of new housing construction in Iowa is multifamily.

Table 2.1. Comparison of 1992 MEC and 2003 IECC Requirements in REScheck ${ }^{\mathrm{TM}}$ Software for Multifamily Residences

\begin{tabular}{|c|c|c|c|c|c|c|c||}
\hline Code & Package & $\begin{array}{c}\text { Window } \\
\text { U-Factor }\end{array}$ & Ceiling & Wall & Floor & $\begin{array}{c}\text { Basement } \\
\text { Wall }\end{array}$ & $\begin{array}{c}\text { Slab } \\
\text { Perimeter }\end{array}$ \\
\hline \hline 1992 MEC & Option A & 0.80 & R-19 & R-13 & R-19 & R-13 & R-2, 2 ft \\
& Option B & 0.50 & R-30 & R-13 & R-11 & None & None \\
\hline 2003 IECC & Option A & 0.50 & R-30 & R-13 & R-11 & R-13 & R-2, 2 ft \\
\hline
\end{tabular}

The IECC allows flexibility in meeting energy efficiency requirements using trade-offs, so that buildings can comply with the code if the annual energy use is sufficiently low, even if individual code requirements are not met. Builders can add several possible improvements to the building design to comply with the more-stringent IECC thermal requirements for walls in multifamily buildings. The requirements depend on the building design (e.g., the window-to-wall area percentage) and the climate where the building will be located. Issues related to insulating basement walls (or basement ceilings if the basements are unheated) were debated when Iowa adopted the 1992 MEC $^{(a)}$ and are not addressed here.

For consistency, if insulation is required in basements in single-family homes, insulation should also be required in multifamily buildings. Beyond basement insulation, modest levels of energy efficiency will likely result in compliance with the IECC for most multifamily buildings. Wood or vinyl windows usually have U-factors as low, or lower (lower is better) than the U-0.50 shown in Table 2.1 for 2003 IECC compliance. Because these types of windows are already widely used in Iowa, this improvement is reasonable. Cost data from California show that vinyl windows cost about the same as aluminum windows (Xenergy, Inc. 2001).

We used the Energy-10 simulation tool with the dimensions specified above to estimate the energy savings from basement insulation in a multifamily building in Des Moines (Sustainable Buildings Industry Council 1999). We assumed a 6,600- $\mathrm{ft}^{2}$ building with a heated basement. We also assumed natural gas heating at $\$ 0.60 /$ therm and electricity at 9 cents $/ \mathrm{kWh}$. The $2 \mathrm{in}$. of exterior foam insulation on the basement wall saved $\$ 77$ per year per dwelling unit. Assuming the highest cost from the Greiner

(a) T. H. Greiner of Iowa State University. Letter to Iowa Building Code Commissioner dated December 11, 1996. Iowa State University, Ames, Iowa. 
(1996) report of $\$ 1400$ for 2 in. of foam insulation and scaling this to a 295 -ft perimeter of the multifamily building gives a cost of about $\$ 3,100$, or an average of $\$ 510$ per dwelling unit. The simple payback will be 7 years for the exterior basement insulation. This assumption is one possible insulation configuration for basements. Heated basements can also be finished and have batt insulation in the framing cavities. Unheated basements can have insulation under the floor above the basement and insulated ducts.

\subsection{Recessed Lighting}

The 2003 IECC specifically requires that recessed (canned) lighting fixtures be carefully sealed. The 1992 MEC does not have this requirement, although it does require that all "openings" in the building envelope be "caulked, gasketed, weatherstripped, or otherwise sealed." Although this requirement may seem like a minor construction detail, unsealed recessed lighting fixtures are a surprisingly large source of air leakage, resulting in increased heating and cooling costs.

The incremental cost of recessed lighting fixtures is about \$5 per fixture (Energy Design Update 1994). We estimate the typical new house may have about 10 of these types of fixtures exposed on the top to an attic or in a cathedral ceiling, although this number can vary dramatically. Our sources indicate airtight recessed lighting is very cost-effective for the homeowner. Research in both the laboratory and in houses indicates that air leaks out of a single typical recessed lighting fixture at about $5 \mathrm{cfm}$ during winter conditions in colder climates, increasing energy costs by $\$ 5$ or more per year (Energy Design Update 1994). We estimate that properly sealing each recessed lighting fixture that is exposed to an attic or other unconditioned space can save \$5 a year in Iowa. Therefore, investing in improved recessed lighting fixture sealing can pay off in energy savings in about one year.

Note that these impacts can only be expected to occur if the specific requirements for recessed lighting are enforced. Enforcing the requirement to use airtight recessed lighting should be straightforward for light fixtures that are labeled as airtight. Airtight fixtures or housings for recessed lighting may already be in use in Iowa, although we suspect these types of fixtures are typically not used. 


\subsection{Impacts from Minor Differences 1992 MEC and 2003 IECC}

The 1992 MEC and 2003 IECC have numerous minor differences that will likely have little or no impact on energy efficiency or construction costs for most residential buildings in Iowa. This section discusses these minor differences and their impacts on construction costs and energy consumption impacts.

\subsection{Assumptions for Determining Wall $U_{0}$-Values for Wood-Frame Walls}

The envelope component heat loss and heat gain ( $U_{0}$ for overall $U$-value) requirements for singlefamily residences did not change between 1992 and 2003 for Iowa locations. A change in referenced standards in the 2003 IECC has indirectly made the 2003 IECC slightly more stringent in terms of wall insulation requirements. The 1992 MEC references an older version of the ASHRAE Handbook of Fundamentals (the 1985 edition) and the 2003 IECC references a newer version of the handbook (the 2001 edition) (ASHRAE 1985, 2001). Previously, the American Society of Heating, Refrigerating and Air-Conditioning Engineers, Inc. (ASHRAE) recommended assuming the framing occupied 15\% of the gross wall area, now ASHRAE recommends 25\%. Because framing (usually wood) loses more heat than insulation between the framing, the 2003 IECC coupled with its referenced standards will give a lessfavorable $\mathrm{U}_{\mathrm{o}}$-value calculation than the1992 MEC for any given wall.

It is possible that many users will determine wall $U_{0}$-values using the same version of the handbook (or other source) regardless of what the code references, in which case the envelope insulation and glazing requirements for single-family buildings will not change at all in Iowa.

- Construction Cost Impacts: The potential increase in construction cost is very slight because most houses that comply with the 1992 MEC will also comply with the 2003 IECC. If a house design barely complies with the 1992 MEC, it may fail to comply with the 2003 IECC. In this case, numerous options exist to make the slight improvements needed to comply with the 2003 IECC. For example, a 2\% increase in furnace efficiency (AFUE) or a 0.04 improvement in the U-factor of the windows should be sufficient. It is expected that construction cost increases related to this issue would be minor-generally zero but no more than about $\$ 100$ in most cases.

- Energy Consumption Impacts: If there is a slight improvement in the energy efficiency of the envelope as a result of the change in wall heat loss/gain calculations, a modest amount of energy can be saved.

\subsection{Protective Covering for Exposed Foundation Insulation}

The 2003 IECC requires that above-grade exposed foundation insulation have a protective covering to protect it from damage. The covering should be "rigid, opaque, and weather resistant," and it must cover the exposed area and extend 6 in. below grade. Many houses do not have any exterior foundation insulation but instead have interior insulation in the floor above basements or crawlspaces or on basement walls. This code requirement would not affect these houses.

- Construction Cost Impacts: In 1996, DFI Pultruded Composites, Inc., in Erlanger, Kentucky, was reported to sell a product called Insul-Guard for \$1.07 and \$2.14 per lineal ft for 12-in.-wide and 24-in.-wide panels, respectively, with quantity discounts available 
(Energy Design Update 1996). For typical houses, total costs may range from $\$ 100$ to $\$ 200$ for the 12-in.-wide panels. Other products and methods of protecting exposed foundation insulation are available, including vinyl or stucco-like coatings. Builders are expected to quickly find the lowest cost methods of protecting exposed foundation insulation.

- Energy Consumption Impacts: The protective covering may lengthen the life of the insulation by preventing damage.

\subsection{Insulation for Vented Crawlspaces}

Insulating the walls of crawlspaces with ventilation openings is no longer an option in the IECC. If the crawlspace is ventilated, insulation on the ceiling of the crawlspace and on conditioned basement walls adjacent to the crawl space is required. The levels (R-values) of insulation have not changed in the 2003 IECC; only the options for placement of the insulation have changed. The reason for this code change is that the vents may be left open in the winter, allowing cold air to flow into the crawlspace, greatly reducing the benefit of the wall insulation.

- Construction Cost Impacts: This requirement may increase the construction cost if the builder prefers ventilated crawlspaces with wall insulation and the updated code forces the builder to insulate the ceiling instead. Insulating the crawlspace walls and not venting the crawlspace is a recommended construction method.

- Energy Consumption Impacts: This requirement may save some energy. When crawlspaces are vented, the 1992 MEC allows the wall of the crawlspace to be insulated instead of the ceiling. The value of crawlspace wall insulation is greatly diminished if the occupants fail to close the vents during the winter.

\subsection{Heat Traps on Water Heaters}

The 2003 IECC requires heat traps on water heaters. A heat trap is a device or an arrangement of piping that keeps the buoyant hot water from circulating through the piping distribution system because of natural convection. Most new water heaters come equipped with heat traps as a standard feature.

- Construction Cost Impacts: The incremental cost is \$2 to \$5 (DOE 2000).

- Energy Consumption Impacts: The energy savings for electric water heaters is 0.20 $\mathrm{MBtu} / \mathrm{yr}$, or $\$ 4.00 / \mathrm{yr}$. The energy savings for natural gas water heaters is $0.48 \mathrm{MBtu} / \mathrm{yr}$, or $\$ 2.81 / y r(D O E$ 2000).

\subsection{Skylight Shaft Insulation}

In the 2003 IECC, skylight shafts 12 in. or greater in depth passing through unconditioned spaces, such as attics, are required to have R-19 insulation. The 1992 MEC includes all building elements separating conditioned spaces from the exterior as part of the "building envelope." Skylight shafts fit this description; thus, the 1992 MEC technically requires that they be insulated or, if not, that the design make up for the lack of insulation elsewhere. However, because this construction element is specifically called out in the 2003 IECC with a clear requirement, skylight shafts are more likely to be insulated. 
- Construction Cost Impacts: No substantial cost impact is expected. Most new houses will not have this construction element.

- Energy Consumption Impacts: This requirement may result in a modest energy savings in houses with skylight shafts.

\subsection{Duct Insulation}

The duct insulation R-value requirements in the 1992 MEC were changed and restructured for the 2003 IECC. In both codes, minimum duct R-values depend on the temperature difference between the air inside the ducts and the air outside the ducts at design (worst-case) conditions. In the 2003 IECC, most supply ducts in unconditioned spaces, such as attics, basements, and crawlspaces, need to be insulated to R-8. Return ducts only need to be insulated to R-4 in attics and R-2 in other unconditioned spaces. In the 1992 MEC, the R-value requirements vary continuously with the temperature difference inside and outside the ducts.

- Construction Cost Impacts: None. The R-8 supply ducts are approximately what the 1992 MEC requires. The duct insulation requirements have not increased and, in fact, may have decreased in many cases.

- Energy Consumption Impacts: No significant impacts are expected. Determining the duct insulation R-value requirements in the 1992 MEC was complicated; thus compliance with these requirements was probably low, particularly when high R-values were required.

\subsection{Duct Sealing}

Duct-sealing provisions in the 2003 IECC apply to all supply and return ducts. Tapes and mastics used to seal ductwork have to meet UL standards. The 1992 MEC did not require sealing for ducts located inside the conditioned space or return air plenums.

- Construction Cost Impacts: Costs for improved duct sealing may vary from zero to several hundred dollars depending on how thoroughly the code is enforced. Significant improvements in duct sealing may raise construction costs by several hundred dollars but is probably a good investment. One study reports a \$214 cost for improved duct sealing (Hammon and Modera 1996).

- Energy Consumption Impacts: Substantial energy savings of $10 \%$ or more from heating and cooling could result from increased emphasis on duct sealing. Improved duct sealing can pay back in a few years.

Comment: Studies have shown that even in new homes in states that have energy efficiency codes, ducts are often poorly sealed and are quite inefficient at delivering heated and cooled air to the registers. The state of Iowa should consider targeting improved duct sealing by training HVAC installers and increasing code enforcement, including spot-testing with a "duct blaster" and similar tests. Other states also leverage above code programs, such as HERS (Home Energy Rating System) ratings, to augment duct testing and training programs. 


\subsection{Window and Door Air Leakage}

The maximum air leakage rates for windows and sliding doors have been decreased to $0.3 \mathrm{ft}^{3}$ per min. per $\mathrm{ft}^{2}$ of area.

- Construction Cost Impacts: No significant impact. The leakage rates maintain consistency with the latest industry standard (AAMA/NWWDA 1997), so most windows probably meet this requirement.

- Energy Consumption Impacts: No significant impact is expected.

\subsection{National Fenestration Rating Council Ratings}

Fenestration products must now be rated by the National Fenestration Rating Council (NFRC) standards for thermal and solar properties, although default values for products not evaluated to the NFRC standards are provided by the 2003 IECC.

- Cost Impact: None. Window manufacturers are not required to have their products rated; default values can be used instead. Over 80,000 window products have now been rated.

- Energy Consumption Impacts: The requirement for rated windows may save some energy by improving accuracy and creating a level playing field. Without the NFRC ratings, windows could readily be purported to have a better U-factor than the true U-factor, lowering energy efficiency.

\subsection{Steel Stud-Framed Buildings}

Criteria have been added to specifically correct for increased heat loss from steel stud framing in exterior walls, ceilings, and floor thermal calculations.

- Construction Cost Impacts: None expected. Exterior steel stud-framed residences are rare and the 2003 IECC criteria are not intended to change the stringency of the code.

- Energy Consumption Impacts: None expected.

\subsection{Prescriptive Path for Additions and Window/Skylight Replacement}

The 2003 IECC contains a new simple prescriptive path (Section 502.2.5) of envelope requirements for replacement windows and for additions less than $500 \mathrm{ft}^{2}$ with a total glazing area no greater than $40 \%$ of the addition's gross wall and roof area. Skylight replacements must have a U-factor of 0.50 or less. This new option for additions and window replacements is not intended to increase or decrease the stringency of the code, but rather provide clear and unambiguous requirements. Determining how to comply with envelope-related code requirements for additions is less clear without this simple approach. Note that the requirements in this path are stringent for Iowa climates: R-49 ceiling insulation, R-21 wall insulation, and U-0.35 windows.

- Construction Cost Impacts: No significant impact is expected. The new prescriptive criteria for additions are an alternative compliance path; the other compliance paths are 
unchanged from the 1992 MEC (unless noted elsewhere in this report). Because this change only adds an extra optional compliance path, it arguably cannot be interpreted as increasing the stringency of the code.

- Energy Consumption Impacts: No significant impact is expected, although this requirement may improve energy efficiency via better code compliance and enforcement for small additions and window replacements.

\subsection{Optional Prescriptive Compliance Approaches - Section 502.2.4 and Chapter 6}

Chapter 6 in the 1992 MEC entitled, "Building Design by Acceptable Practice," has been integrated into Chapter 5 of the 2003 IECC (Section 5.2.2.3). A new Chapter 6 has been added to the 2003 IECC that contains a 4-page optional and standalone prescriptive compliance approach for residential buildings. This approach can be used only if the window area is less than or equal to $15 \%$ of the wall area for a single-family building, and less than or equal to $25 \%$ of the wall area for a multifamily building. A more extensive prescriptive approach that allows almost any window area percentage has been added to the IECC in Section 502.2.4.

- Construction Cost Impacts: None. This change in Chapter 6 is only structural. Because this new version of Chapter 6 simply repackages other requirements in the IECC, it is not intended to create any new or different requirements-only a simpler and more concise prescriptive approach. The prescriptive packages in Section 502.2.4 and Chapter 6 are based on implementing the criteria of IECC Table 502.2 and its associated figures for typical construction. These packages are not intended to change the energy efficiency of the code, although they were developed with conservative assumptions to ensure energy efficiency is not decreased.

- Energy Consumption Impacts: None expected.

\subsection{Expanded Set of Rules for System Analysis Approach - Chapter 4}

Chapter 4 in both the 1992 MEC and 2003 IECC permits compliance via a systems analysis approach, also known as a "performance" path. This approach allows any building design to comply with the code if the builder can show that the proposed building has sufficiently low annual energy use. Software specifically designed to simulate building energy use would normally be used to show compliance. The basic performance approach in the code has not changed since 1992; however, the expanded "ground rules" (directions on how to perform this analysis) have changed. The 2003 IECC contains fairly detailed directions on what assumptions should be made in the analysis whereas the 1992 MEC does not provide these detailed directions. For example, the 2003 IECC specifies that in the input to the simulation software, the thermostat should be set at $68^{\circ} \mathrm{F}$ for heating with a nighttime setback to $63^{\circ} \mathrm{F}$, and set to $78^{\circ} \mathrm{F}$ for cooling. The $1992 \mathrm{MEC}$ does not provide any guidance on thermostat operation.

The 2003 IECC also sets stringent baseline requirements for the "Standard Design" wall and fenestration (windows). The performance path has requirements that are more stringent than those in the prescriptive requirements in Chapter 5 of the IECC for most designs. 
- Construction Cost Impacts: Small; usually none. These expanded rules were intended to provide clarification on how to perform the analysis to estimate annual energy use, not to make the code more or less stringent. However, the 2003 IECC has new, lower wall and fenestration U-values for the "Standard Design" that may effectively make the code more stringent for many residential buildings if the performance path is used. Because the Chapter 4 approach is only one of several options in terms of compliance paths, this change does not necessarily mean higher construction costs. In fact, the Chapter 4 compliance approach may be infrequently used because it is the most complicated approach (although user-friendly software can make this approach much more attractive).

- Energy Consumption Impacts: This change may improve energy efficiency in homes when the performance path (the Chapter 4 methodology) is used.

\subsection{Solar Heat Gain Coefficient Requirement of 0.4 in Warm Climates}

Glazed fenestration products (windows, skylights, doors with windows) are limited to a maximum 0.4 solar heat gain coefficient (SHGC) in climates with less than 3500 heating degree-days. From a national perspective, this requirement is perhaps the most notable residential requirement in the 2003 IECC that is not in the 1992 MEC. However, this requirement does not affect Iowa because Iowa does not have locations with heating degree-days this low (Iowa heating degree-days are from 5500 to 8000).

- Construction Cost Impacts: None.

- Energy Consumption Impacts: None.

\subsection{Sunroom Additions}

The 2003 IECC has special requirements for sunroom additions. The sunroom may have lower levels of energy efficiency for its walls (R-13), windows (U-0.50), and ceilings (R-24) than otherwise would apply to these envelope components in the IECC. To qualify, the sunroom addition must

- Be capable of being controlled as a separate zone.

- Not be used as kitchens or sleeping rooms.

- Meet the envelope requirements of the IECC for any new walls, doors, or windows between the sunspace and the house.

- Have the glazing area be in excess of $40 \%$ of the gross area of the exterior walls and roof of the sunroom.

These requirements do not apply to sunrooms in new houses, only additions to existing housing.

- Construction Cost Impacts: Will reduce costs of sunroom additions.

- Energy Consumption Impacts: Will increase energy use if the occupants keep the sunroom heated and cooled. 


\subsection{References}

American Architectural Manufacturers Association and National Wood Window and Door Association (AAMA/NWWDA). 1997. ANSI/AAMA/NWWDA 101/I.S.2.97, "Voluntary Specifications for Aluminum, Vinyl (PVC) and Wood Windows and Glass Doors.” Schaumberg, Illinois.

American Society of Heating, Refrigerating and Air-Conditioning Engineers, Inc. (ASHRAE). 2001. 2001 ASHRAE Handbook - Fundamentals. Atlanta, Georgia.

American Society of Heating, Refrigerating and Air-Conditioning Engineers, Inc. (ASHRAE). 1985. 1985 ASHRAE Handbook - Fundamentals. Atlanta, Georgia.

Council of American Building Officials (CABO). 1992. 1992 Model Energy Code. Falls Church, Virginia.

Energy Design Update. May 1996. “Fiberglass Foundation Insulation Covering.” 16(5):14.

Energy Design Update. January 1994. “Air and Moisture Leakage Through Recessed Ceiling Light Fixtures.” 14(1):6-7.

Hammon, R. W., and M. P. Modera. 1996. "Improving the Efficiency of Air Distribution Systems in New California Homes." In Proceedings for the 1996 ACEEE Summer Study, vol. 2, p. 85. American Council for an Energy-Efficient Economy, Washington, D.C.

International Code Council (ICC). 2003. 2003 International Energy Conservation Code. Falls Church, Virginia.

International Code Council (ICC). 1999. 2000 International Energy Conservation Code. Falls Church, Virginia.

Lucas, R. G. 2002. Assessment of Impacts from Updating Iowa’s Residential Energy Code to Comply with the 2003 International Energy Conservation Code. PNNL-14090. Pacific Northwest National Laboratory, Richland, Washington.

Sustainable Buildings Industry Council. 1998. Energy-10 Software, Version 1.2. Washington, D.C.

U.S. Department of Energy (DOE). 2000. Water Heater Rulemaking Technical Support Document, [Online report]. Available URL:

http://www.eren.doe.gov/buildings/codes_standards/reports/waterheater/index.html.

Xenergy, Inc. 2001. 2001 DEER Update Study_Final Report. Oakland, California. 


\section{Appendix}

\section{Comparison of the 2003 IECC to the 2000 IECC}

The International Code Council (ICC) has recently issued the 2003 editions of their family of codes, including the International Energy Conservation Code (IECC). The requirements for residential buildings in the 2003 IECC are largely the same as those in the 2000 IECC. Increased duct insulation and lenient envelope requirements for sunroom additions are the main changes. Other changes to the code are minor and have little or no effect on code stringency.

Duct insulation requirements have changed from the R-5 or R-3.3 required in the 2000 IECC. In the 2003 code, duct insulation levels are set based on heating degree-days (hdd), duct location, and duct type (supply or return). Supply and return ducts in attics are generally required to have R-8 and R-4 insulation, respectively. Ducts in other unconditioned spaces such as basements, crawlspaces, and garages generally have requirements of R-4 to R-8 for supply ducts and R-2 for return ducts.

A special set of requirements has been added to the code for sunroom additions. Sunroom additions are permitted to have ceiling, wall insulation, and window U-factor requirements typically less stringent than the requirements for all other types of residential construction. To qualify, the sunroom addition must

- Be capable of being controlled as a separate zone.

- Not be used as kitchens or sleeping rooms.

- Meet the envelope requirements of the IECC for any new walls, doors, or windows between the sunspace and the house.

- Have the glazing area be in excess of $40 \%$ of the gross area of the exterior walls and roof of the sunroom.

Requirements tables were added for steel-frame ceilings and floors that complement already existing IECC steel wall requirements. Providing simple methods of complying with steel-framed building codes, these tables are intended to provide requirements equivalent in energy efficiency to those already in the code for wood-framed ceilings and floors.

The performance path in Chapter 4 of the IECC contains a variety of modest improvements that make the chapter simpler and briefer. For example, unnecessary text about crediting renewable energy has been deleted. Other changes enhance the accuracy or completeness of the requirements or make them more sensible (e.g., internal heat gain assumptions improved).

There are two changes that can increase the stringency of the code in certain cases. First, any house proposed to use electric resistance heating must be compared against the "standard design" having an electric air source heat pump. This change makes the performance approach more stringent for electric resistance heating designs. Second, a provision has been added that the worst possible orientation, in terms of energy use, be assumed for a group of residences in a development with identical designs. 
An additional change allows climate zones identified in Chapter 3 to now be used with the prescriptive envelope requirements in Chapter 6 and Section 502.2.4 of the code. These prescriptive tables can be used with either the hdd or the Chapter 3 climate zone maps, whereas in the 2000 IECC, only hdd could be used. For most locations, the Chapter 3 climate zones and hdd lead to the same envelope requirements. Using the climate map zones in the maps instead of the hdd will allow about $10 \%$ of cities nationwide to have less stringent prescriptive requirements. However, about $20 \%$ of cities nationwide will have more stringent requirements when the climate zones are used with the prescriptive requirements. This change brings consistency between the IECC, the International Residential Code, and the REScheck ${ }^{\mathrm{TM}}$ compliance materials developed by the U.S. Department of Energy. REScheck has always used the map-based climate zones for its prescriptive requirements.

Many of the changes to the IECC are intended to improve code wording. Definitions have been added, and some terminology has changed. Residential building definitions were revised to better align with the IRC and International Mechanical Code definitions. The A-1 and A-2 residential designations are no longer used-they have been replaced with the R-2 and R-4 classifications from the International Building Code (IBC) and the term "detached one- and two-family dwellings." 